\title{
Phenotypic Characteristics and Copy Number Variants in a Cohort of Colombian Patients with VACTERL Association
}

\author{
Olga M. Moreno ${ }^{a}$ Ana I. Sánchez ${ }^{a, b, c}$ Angélica Herreño ${ }^{a} \quad G^{2}$ stavo Giraldo ${ }^{a}$ \\ Fernando Suárez $^{a}$ d Juan Carlos Prieto ${ }^{a}$ Ana Shaia Clavijo ${ }^{a}$ Mercedes Olaya $^{\text {e }}$ \\ Yaris Vargas $^{f} \quad$ Javier Benítez $^{g} \quad$ Jordi Surallés $^{\mathrm{h}} \quad$ Adriana Rojas $^{\mathrm{a}}$ \\ anstituto de Genética Humana, Facultad de Medicina, Pontificia Universidad Javeriana, Bogotá, Colombia; \\ ${ }^{b}$ Departamento Materno Infantil, Facultad de Ciencias de la Salud, Pontificia Universidad Javeriana, Cali, Colombia; \\ 'Centro Médico Imbanaco de Cali, Cali, Colombia; 'Unidad de Genética Medica, Hospital Universitario de \\ San Ignacio, Bogotá, Colombia; eServicio de Patología, Hospital Universitario de San Ignacio, Bogotá, Colombia; \\ fServicio de Pediatría, Neonatología, Hospital Universitario de San Ignacio, Bogotá, Colombia; ${ }^{9} \mathrm{CNIO}$ : Centro \\ Nacional de Investigaciones Oncológicas, Madrid, Spain; hepartamento de Genética y Microbiología, Universidad \\ Autónoma de Barcelona, Barcelona, Spain
}

\section{Keywords}

Array-CGH · Chromosomal microalterations · Congenital malformations · Copy-number variants · Fanconi anemia . VACTERL association

\begin{abstract}
VACTERL association (OMIM 192350) is a heterogeneous clinical condition characterized by congenital structural defects that include at least 3 of the following features: vertebral abnormalities, anal atresia, heart defects, tracheoesophageal fistula, renal malformations, and limb defects. The nonrandom occurrence of these malformations and some familial cases suggest a possible association with genetic factors such as chromosomal alterations, gene mutations, and inherited syndromes such as Fanconi anemia (FA). In this study, the clinical phenotype and its relationship with the presence of chromosomal abnormalities and FA were evaluated in 18 patients with VACTERL association. For this, a Gbanded karyotype, array-comparative genomic hybridization, and chromosomal fragility test for FA were performed.
\end{abstract}

karger@karger.com www.karger.com/msy

Karger $\stackrel{\text { ' }}{=}$

GOPEN ACCESS
(C) 2020 The Author(s)

Published by S. Karger AG, Basel

This is an Open Access article licensed under the Creative Commons Attribution-NonCommercial-4.0 International License (CC BY-NC) (http://www.karger.com/Services/OpenAccessLicense), applicable to the online version of the article only. Usage and distribution for commercial purposes requires written permission.
All patients (10 female and 8 male) showed a broad clinical spectrum: 13 (72.2\%) had vertebral abnormalities, 8 (44.4\%) had anal atresia, 14 (77.8\%) had heart defects, 8 (44.4\%) had esophageal atresia, 10 (55.6\%) had renal abnormalities, and $10(55.6 \%)$ had limb defects. Chromosomal abnormalities and FA were ruled out. In 2 cases, the finding of microalterations, namely del(15)(q11.2) and dup(17)(q12), explained the phenotype; in 8 cases, copy number variations were classified as variants of unknown significance and as not yet described in VACTERL. These variants comprise genes related to important cellular functions and embryonic development.

(C) 2020 The Author(s)

Published by S. Karger AG, Basel

\section{Introduction}

VATER association was first described by Quan and Smith in 1972 as a statistically nonrandom co-occurrence of a group of different multisystem congenital malformations, including vertebral anomalies (V), anal atresia (A), 
tracheoesophageal (TE) fistula with or without esophageal atresia, and renal malformations (R) [Quan and Smith, 1972, 1973]. The complete phenotype delineation occurred in 1996 and included cardiac defects (C) and limb anomalies (L) (VACTERL) (OMIM 192350) [Rittler et al., 1996]. VACTERL with hydrocephalus VACTERL$\mathrm{H}$ (OMIM 276950) is a more severe condition that has been associated with autosomal recessive or X-linked inheritance (OMIM 314390) [Porteous et al., 1992; Alter and Rosenberg, 2013; Jung et al., 2020]. Because these malformations have been observed to occur together more often than would be expected by chance, the condition was termed an association. VACTERL association is typically defined by the presence of at least 3 of the congenital malformations mentioned above. VACTERL association is a relatively common condition, with an incidence estimated at 1 in 10,000-40,000 live-born infants [Siebel and Solomon, 2013].

To date, there is no known evidence for a single unifying cause that would result in the condition. Because VACTERL association is likely to be causally heterogeneous, only a few studies have sought genetic or other causal explanations among large cohorts of affected individuals [Solomon et al., 2010a, b; Solomon, 2011; Saisawat et al., 2014; Hilger et al., 2015]. It was recently identified that recessively inherited mutations in the genes TRAP1 and ZIC3 (the latter linked to the X chromosome), associated with the pathophysiology of VACTERL, are a monogenic cause of this condition [Saisawat et al., 2014; Hilger et al., 2015]. Moreover, it was proposed that the FOXF1 gene may also be a candidate [Stankiewicz et al., 2009; Shaw-Smith, 2010; Hilger et al., 2015]. Based on experimental animal models, it has been suggested that genes related to the Sonic hedgehog (Shh) pathway may be involved in the phenotype [Kim et al., 2001; Tumini et al., 2019], as well as genes that act on mitochondrial and ciliary function [Thauvin-Robinet et al., 2006; Siebel and Solomon, 2013; Hilger et al., 2015].

Additional evidence supporting genetic causes of VACTERL association is derived from case reports. These studies have also provided insight into different chromosomal deletions and microduplication/microdeletion variants that might explain the phenotype. For example, deletions at $13 \mathrm{q}$ and microduplications of different sizes at $1 \mathrm{q} 41,2 \mathrm{q} 37.3,8 \mathrm{q} 24.3,22 \mathrm{q} 11.21$, and Xq25q27.3 have been detected in patients [Schramm et al., 2011; Dworschak et al., 2013; Hilger et al., 2013, 2015; Puvabanditsin et al., 2016].

On the other hand, this heterogeneous condition has many overlapping defects with other malformation syn- dromes, and it is usually considered a diagnosis of exclusion; thus, accurate diagnosis can be quite challenging [Siebel and Solomon, 2013]. Phenotypically overlapping disorders of VACTERL association include Fanconi anemia (FA), Baller-Gerold syndrome, CHARGE syndrome, deletion 22q11.2 syndrome, MURCS association, oculoauriculo-vertebral syndrome, Opitz G/BBB syndrome, Pallister-Hall syndrome, Feingold syndrome, Holt-Oram syndrome, Townes-Brocks syndrome, and VACTERL$\mathrm{H}$, among others [Siebel and Solomon, 2013; Chen et al., 2016].

In fact, patients with FA often exhibit multiple congenital malformations, suggesting a diagnosis of VACTERL association [Fiesco-Roa et al., 2019]. Furthermore, patients with clinically suspicious VACTERL-H have been found to have pathogenic variants in different FANC genes, and they have accordingly been reclassified as having FA [Holden et al., 2006]. Because of the above, a common pathophysiology pathway for VACTERL and FA patients involving Shh genes has been proposed [Lubinsky, 2015]. As much as $5-10 \%$ of patients clinically diagnosed with VACTERL-H instead have FA; therefore, FA must be considered one of the most important differential diagnoses among these patients [Alter and Rosenberg, 2013].

The aim of this study was to assess the clinical characteristics of a cohort of Colombian patients who met the diagnostic criteria for VACTERL association and to identify chromosomal rearrangements by conventional and molecular cytogenetics, in addition to determining the cellular phenotype of FA, to contribute to the knowledge of the genetic causes of the disease.

\section{Patients and Methods}

Eighteen pediatric patients with high clinical suspicion of VACTER/VACTERL association were included.

\section{Clinical Data}

All data regarding clinical features were obtained by physical examination or from clinical reports; these data were analyzed to describe clinical aspects. Our analysis was based on clinical records from patients who met the criteria for VACTERL. When a diagnosis of VACTERL was suspected by any medical specialist, the patient was referred to our center to be examined by medical geneticists. All patients received medical care and were followed up by different specialists. The diagnostic workup began with the outpatient clinic visit or in the neonatal care unit where the main clinical and genealogical data were collected. Patient records were collected and archived in specifically dedicated files. VACTERL association was diagnosed in patients who met at least 3 of the 6 criteria (vertebral defects, anal atresia, cardiac defects, 
Table 1. Clinical characteristics of patients with VACTERL association

\begin{tabular}{|c|c|c|c|c|c|c|c|c|c|c|c|}
\hline 3 & $5 y$ & $\mathrm{~F}$ & + & + & + & - & - & + & - & 2 & 4 \\
\hline 5 & 1 y $8 \mathrm{~m}$ & $\mathrm{~F}$ & + & - & + & + & + & - & - & 0 & 4 \\
\hline 6 & $2 y 5 m$ & $\mathrm{M}$ & + & - & + & + & + & - & - & 1 & 4 \\
\hline 9 & $4 y$ & $\mathrm{~F}$ & - & + & + & - & - & + & + & 2 & 4 \\
\hline 10 & $18 \mathrm{~d}$ & $\mathrm{~F}$ & + & - & + & - & - & - & + & 2 & 3 \\
\hline 11 & $4 d$ & M & - & - & - & + & + & + & + & 1 & 4 \\
\hline 12 & $3 y 8 m$ & $\mathrm{~F}$ & + & - & + & - & - & - & + & 4 & 3 \\
\hline 13 & $3 d$ & $\mathrm{~F}$ & + & + & + & - & - & - & - & 1 & 3 \\
\hline 19 & $15 y$ & $\mathrm{~F}$ & + & - & + & - & - & + & + & 3 & 4 \\
\hline 20 & 1 y $2 \mathrm{~m}$ & $\mathrm{M}$ & + & - & + & - & - & + & - & 2 & 3 \\
\hline 21 & $17 y$ & M & + & + & + & - & - & + & + & 4 & 5 \\
\hline \multicolumn{3}{|c|}{ Total cases } & 13 & 8 & 14 & 8 & 6 & 10 & 10 & 14 & 18 \\
\hline
\end{tabular}

y, years; m, months; d, days; F, female; M, male; +, present; -, absent.

tracheoesophageal fistula/esophageal atresia, renal dysplasia, and limb anomalies). Common newborn findings, such as vesicoureteral reflux and patent ductus arteriosus, were not considered major anomalies to warrant inclusion as a component feature unless another anomaly affecting the same organ system was present simultaneously. The final diagnosis of VACTERL was made after excluding other genetic syndromes with overlapping phenotypes.

\section{Conventional Cytogenetics}

To evaluate the possible genetic causes of VACTERL association, a complete cytogenetic analysis was performed. Peripheral blood lymphocytes were cultured in RPMI 1640 medium (Sigma), $10 \%$ fetal bovine serum (Eurobio), and phytohemagglutinin (Gibco), synchronized with amethopterin $\left(1 \times 10^{-5} \mathrm{M}\right.$; Sigma) and unlocked with thymidine $\left(2.4 \times 10^{-6} \mathrm{~g} / \mathrm{mL}\right.$; Sigma $)$ to obtain prometaphase chromosomes. G-banding was performed for all patients. Chromosomes were treated with $0.025 \mathrm{~N} \mathrm{HCl}$ (Merck), followed by incubation in $1 \times$ SSC buffer and Wright (Merck) staining to obtain the G-banding. For each patient, 25 metaphases were analyzed with a resolution of 550-700 bands. Chromosome breakage analyses for FA were performed by using standard procedures [Auerbach, 1988]. Peripheral blood lymphocytes were cultured in RPMI medium plus $10 \%$ fetal bovine serum and phytohemagglutinin and then incubated for $24 \mathrm{~h}$ at $37^{\circ} \mathrm{C}$. For each individual, 2 cultures were treated with butadiene diepoxide (DEB) (100 ng/mL; Alfa Aesar) and incubated for $48 \mathrm{~h}$ under the same conditions; 2 other cultures were not treated with DEB. Chromosomes in metaphase were ob- tained by standard procedures and stained with Giemsa (Merck). Chromosomal breaks and exchanges were evaluated in nonbanded chromosomes as recommended in the literature [Auerbach, 1988]. At the end of the procedure, the percentage of aberrant cells (cells with chromosomal breakages, fragments, rearrangements, exchanges or radial figures), breakages per cell, and breakages per aberrant cell were analyzed, and the percentage of multiaberrant cells (cells with 2 or more breakages or alterations) was calculated. In addition, the total number of breakages and exchanges per cell was determined.

\section{Molecular Cytogenetics}

Genomic DNA was isolated from peripheral blood samples by using the salting-out procedure according to the modified protocol described by Miller et al. [1988]. Lysis of red blood cells was performed with ammonium chloride and SDS. Precipitation of proteins was performed with ammonium acetate, and precipitation of DNA was performed with isopropanol. The DNA was preserved in TE solution (10 mM Tris- $\mathrm{HCl}, \mathrm{pH} 1.4$ and $1 \mathrm{~mm}$ EDTA, $\mathrm{pH} 8$ ) and stored at $-20^{\circ} \mathrm{C}$ until analysis. Array-comparative genomic hybridization (aCGH) was performed for each individual by using Agilent ${ }^{\circledR}$ SurePrint G3 Human CGH Microarray $180 \mathrm{~K}$ and Cytogenomics software v. 4.0.3.12 Agilent ${ }^{\circledR}$. Copy number variations were evaluated by using the following databases: http:// dgvbeta.tcag.ca/dgv/app/home?ref=GRCh37/hg19, https://decipher.sanger.ac.uk/, http://dbsearch.clinicalgenome.org/search/, www.omim.org, and https://www.uniprot.org/uniprot. 


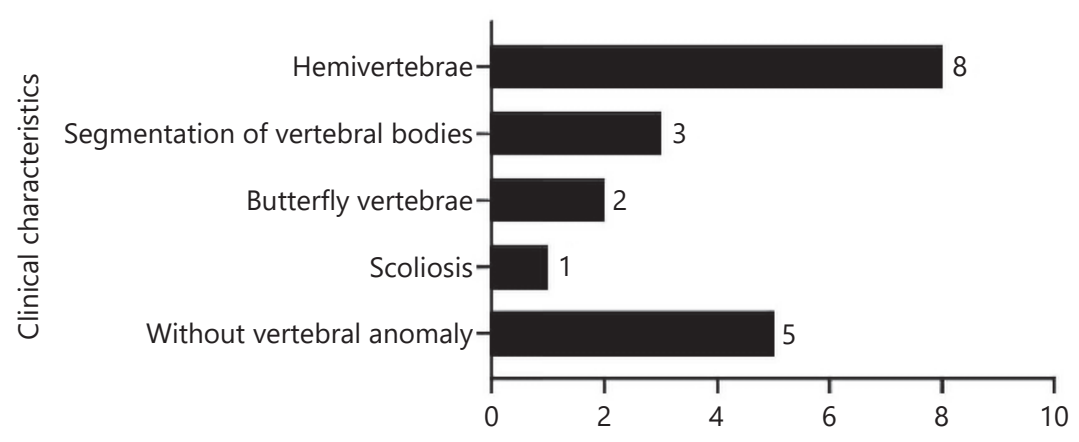

a

Number of cases

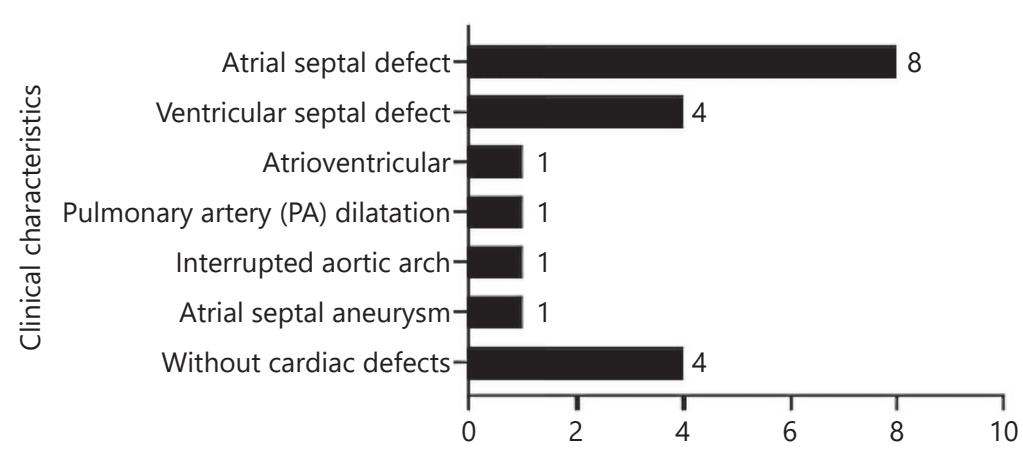

b

Number of cases

Fig. 1. Type and frequency of congenital malformations that occurred non-randomly in the 18 patients with VACTERL association. a Vertebrae congenital anomalies. b Heart defects. c Renal birth defects. d Limb birth defects. Each figure shows the number of cases presenting each characteristic.
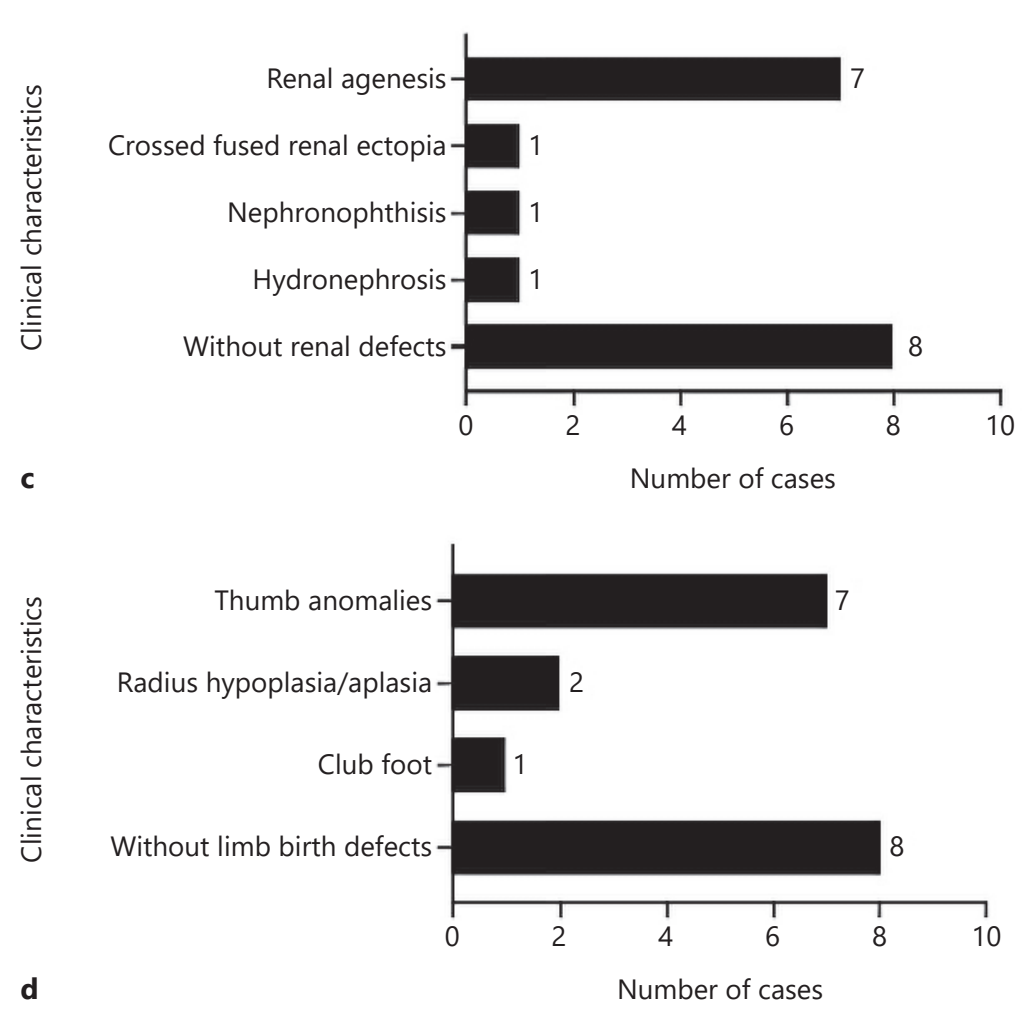


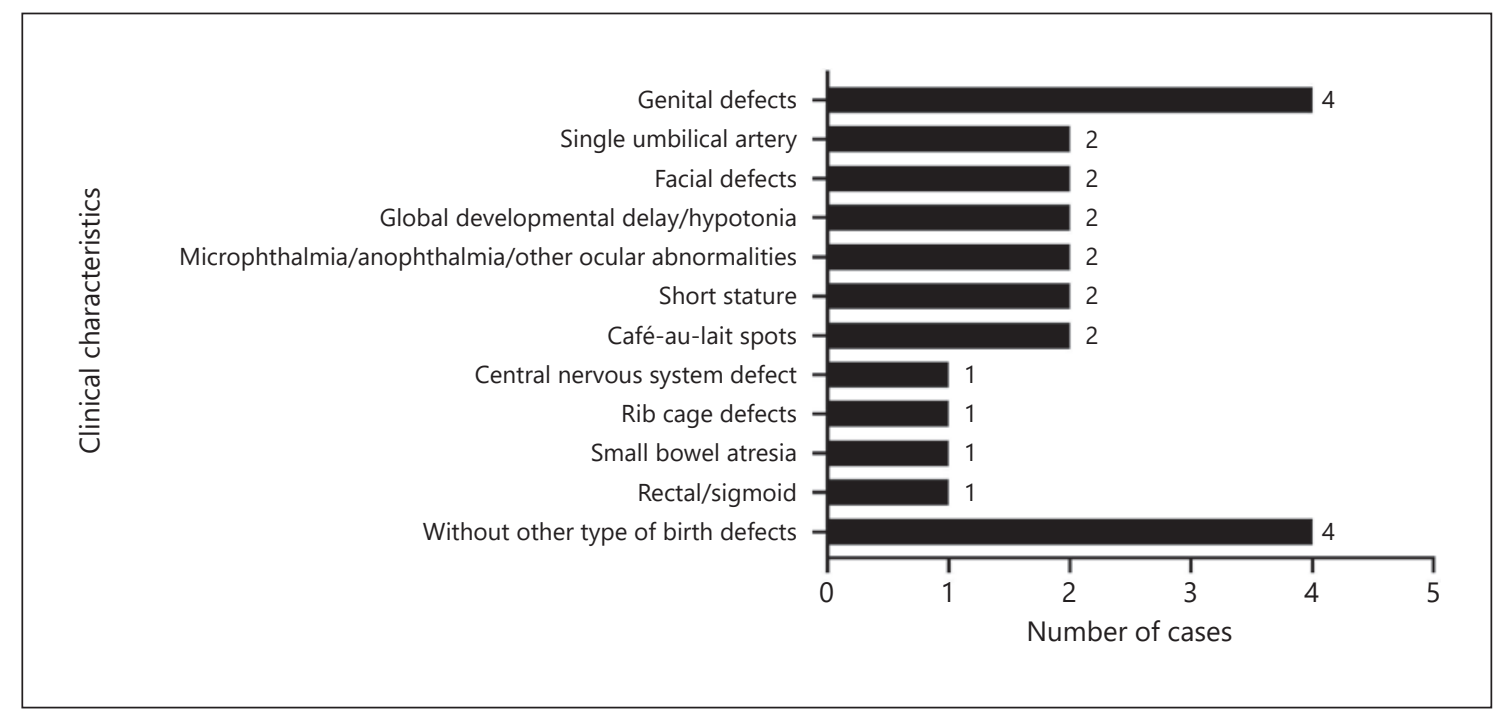

Fig. 2. Other types of birth defects in our patients, not usually reported in the VACTERL spectrum. The figure shows the number of cases presenting each characteristic.

\section{Results}

We evaluated 18 patients who met the criteria for VACTERL association. The female to male ratio was 1.2, with 10 female patients and 8 male patients. Ages at the time of the first clinical examination varied from 3 days to 17 years old. Eight patients $(44.4 \%)$ were under 1 year old, 8 patients (44.4\%) ranged between 1 and 5 years old, and 2 patients $(11.2 \%)$ were teenagers. The clinical features of all patients are described in Table 1.

Thirteen patients $(72.2 \%)$ had vertebral anomalies. Anal atresia was evident in 8 patients (44.4\%). Congenital heart defects were seen in 14 patients $(77.8 \%)$. Esophageal atresia was diagnosed in 8 patients (44.4\%), 6 of whom had a tracheoesophageal fistula. Ten individuals (55.6\%) had renal anomalies. Limb defects were observed in 10 patients (55.6\%). Each specific birth defect is provided in Figure 1. Fourteen of 18 patients (77.8\%) showed additional systemic features of the VACTERL association spectrum, with a nonspecific pattern of VACTERL-type birth defects, including genital abnormalities, single umbilical artery, and anophthalmia. These birth defects are shown in Figure 2.

All patients had normal karyotypes. The analysis of chromosomal breakages with DEB for FA was negative, with an average breakage per cell of 0.12 , thus being within the normal range $(0.02-0.37)$ for individuals not affected by FA.

Molecular cytogenetic analysis was performed for $15 \mathrm{pa}-$ tients; in 2 cases, the parents were also analyzed, whereas the DNA of another 3 cases was not of sufficient quality for the analysis. No gene dose alterations or copy number variations (CNVs) were detected in 5 cases (cases 2, 3, 6, 8, and 20 ). Interestingly, 8 patients had CNVs based on aCGH results classified as variants of unknown significance (VUS). This classification was obtained by using these databases: http://dgvbeta.tcag.ca/dgv/app/home?ref=GRCh37/hg19, www.omim.org, https://decipher.sanger.ac.uk/, and specialized literature (online suppl. Table 1, see www.karger. com/doi/10.1159/000510910). These CNVs have not been previously reported in individuals with phenotypes similar to those of our patients. The regions harbor genes shown in Table 2. Two patients (cases 11 and 19) had abnormal aCGH results. Patient 11 (male) exhibited a duplication of $1.4 \mathrm{Mb}$ at $17 \mathrm{q} 12$ (arr[GRCh37] 17q12(34817422_36243028) $\times 3$ ) classified as pathogenic (Fig. 3). Patient 19 (female) harbored a deletion of $443 \mathrm{~kb}$ at 15q11.2 (arr[GRCh37] 15q11.2(22765628_23208901) $\times 1)$ classified as a VUS with variable expression and incomplete penetrance. Her healthy mother, without any birth defect, was a carrier of the same CNV.

\section{Discussion}

VACTERL association, which usually requires at least 3 component features and the absence of evidence for an overlapping condition, is characterized as a heterogeneous condition with different environmental or genetic 
Table 2. Results of aCGH analyses in 10 patients with VACTERL association: genes involved and their function

\begin{tabular}{|c|c|c|c|c|c|c|}
\hline Patient & $\begin{array}{l}\text { Type } \\
\text { of CNV }\end{array}$ & $\begin{array}{l}\text { Location } \\
(\text { size, } \mathrm{kb})\end{array}$ & $\begin{array}{l}\text { Genomic coordinates, } \\
\operatorname{arr}[\text { GRCh37] }\end{array}$ & Genes & Name/function of the genes & Reference \\
\hline \multirow[t]{2}{*}{9} & \multirow[t]{2}{*}{ del } & \multirow[t]{2}{*}{$1 \mathrm{p} 35.3(100)$} & \multirow[t]{2}{*}{$\begin{array}{l}\text { chr1:28,947,613- } \\
29,047,557\end{array}$} & $T A F 12$ & $\begin{array}{l}\text { TATA-box binding protein associated factor } 12 \\
\text { Transcription and transcription regulation } \\
\text { Detected in all tissues }\end{array}$ & Gazit et al., 2009 \\
\hline & & & & $G M E B 1$ & $\begin{array}{l}\text { Glucocorticoid modulatory element-binding } \\
\text { protein } 1 \\
\text { Regulator of oxidative stress-induced apoptosis } \\
\text { Ubiquitous expression }\end{array}$ & $\begin{array}{l}\text { Nakagawa et al., } \\
2008\end{array}$ \\
\hline 11 & dup & $17 q 12(1,400)$ & $\begin{array}{l}\text { chr17:34,817,422- } \\
36,243,028\end{array}$ & $\begin{array}{l}\text { ZNHIT3, PIGW, } \\
A C A C A, H N F 1 B \\
\text { and others }\end{array}$ & 17q12 microduplication syndrome & $\begin{array}{l}\text { Bierhals et al., } \\
\text { 2013; Mitchell } \\
\text { et al., } 2015\end{array}$ \\
\hline 12 & dup & $14 q 24.2(249)$ & $\begin{array}{l}\text { chr14:71,376,123- } \\
71,625,114\end{array}$ & $P C N X 1$ & $\begin{array}{l}\text { Pecanex-like protein } 1 \\
\text { In Drosophila it is related to Notch signaling } \\
\text { Expression in all tissues }\end{array}$ & $\begin{array}{l}\text { Yamakawa et al., } \\
2018\end{array}$ \\
\hline 13 & dup & $12 \mathrm{p} 12.1(41)$ & $\begin{array}{l}\text { chr12:21,580,444- } \\
21,621,404\end{array}$ & PYROXD1 & $\begin{array}{l}\text { Pyridine nucleotide-disulfide oxidoreductase } \\
\text { domain-containing protein } 1 \\
\text { Oxidoreductase; cellular oxidative stress response } \\
\text { Expression in all tissues }\end{array}$ & Saha et al., 2018 \\
\hline \multirow[t]{6}{*}{14} & \multirow[t]{6}{*}{ dup } & \multirow[t]{6}{*}{$18 p 11.32(529)$} & \multirow[t]{6}{*}{$\begin{array}{l}\text { chr18:131,700- } \\
661,043\end{array}$} & USP14 & $\begin{array}{l}\text { Ubiquitin carboxyl-terminal hydrolase } 14 \\
\text { Proteasome-associated deubiquitinase, autophagia } \\
\text { Expression in all tissues }\end{array}$ & Kim et al., 2018 \\
\hline & & & & THOC1 & $\begin{array}{l}\text { THO complex subunit 1; part of TREX } \\
\text { (transcription and export) complex } \\
\text { Apoptosis regulator, transcription regulation } \\
\text { Expression in all tissues }\end{array}$ & $\begin{array}{l}\text { Wang et al., 2007; } \\
\text { Heath et al., } 2016\end{array}$ \\
\hline & & & & COLEC12 & $\begin{array}{l}\text { Collectin-12 } \\
\text { Promotes phagocytosis, involved in host defense } \\
\text { Expression in endothelial cells (placenta and other } \\
\text { tissues) } \\
\text { Evolutionarily conserved gene in vertebrates }\end{array}$ & Graham et al., 2011 \\
\hline & & & & CETN1 & $\begin{array}{l}\text { Centrin-1 } \\
\text { Cell division functions: role in microtubule- } \\
\text { organizing center structure and function, and cilia } \\
\text { formation } \\
\text { Cytoplasmic expression in spermatids and } \\
\text { spermatocytes }\end{array}$ & $\begin{array}{l}\text { Errabolu et al., } \\
1994\end{array}$ \\
\hline & & & & CLUL1 & $\begin{array}{l}\text { Clusterin-like protein } 1 \\
\text { Role in microtubule-organizing center structure } \\
\text { and function, functional role during photoreceptor } \\
\text { differentiation } \\
\text { Expression mainly in retina }\end{array}$ & $\begin{array}{l}\text { Talmud et al., } \\
\text { 2009; Winkler } \\
\text { et al., } 2018\end{array}$ \\
\hline & & & & TYMSOS & $\begin{array}{l}\text { TYMS opposite strand protein } \\
\text { Expression in all tissues }\end{array}$ & UniProt $^{\mathrm{a}}$ \\
\hline
\end{tabular}

causes not yet well understood. However, there are efforts to clarify the whole phenotypic spectrum as well as the underlying genotype [Solomon et al., 2014].

All patients in our study exhibited a wide clinical spectrum of birth defects. The results from this study highlight several important findings regarding VACTERL association, which remains a poorly understood condition. Cardiac defects, followed by esophageal and vertebral defects, were the most common types of birth defects in this cohort of patients. Although the literature contains some controversy regarding the inclusion of certain features for the diagnosis of VACTERL [Temtamy and Miller, 1974; Miller et al., 1988; Rittler et al., 1996; Solomon, 2011], vertebrae anomalies, heart defects, and esophageal atresia were observed in over half of our patients, which is in accordance with the worldwide literature [Husain et al., 2018]. Renal defects were also seen in $55.6 \%$ of our patients, which is similar to the reports of other cohorts, 
Table 2 (continued)

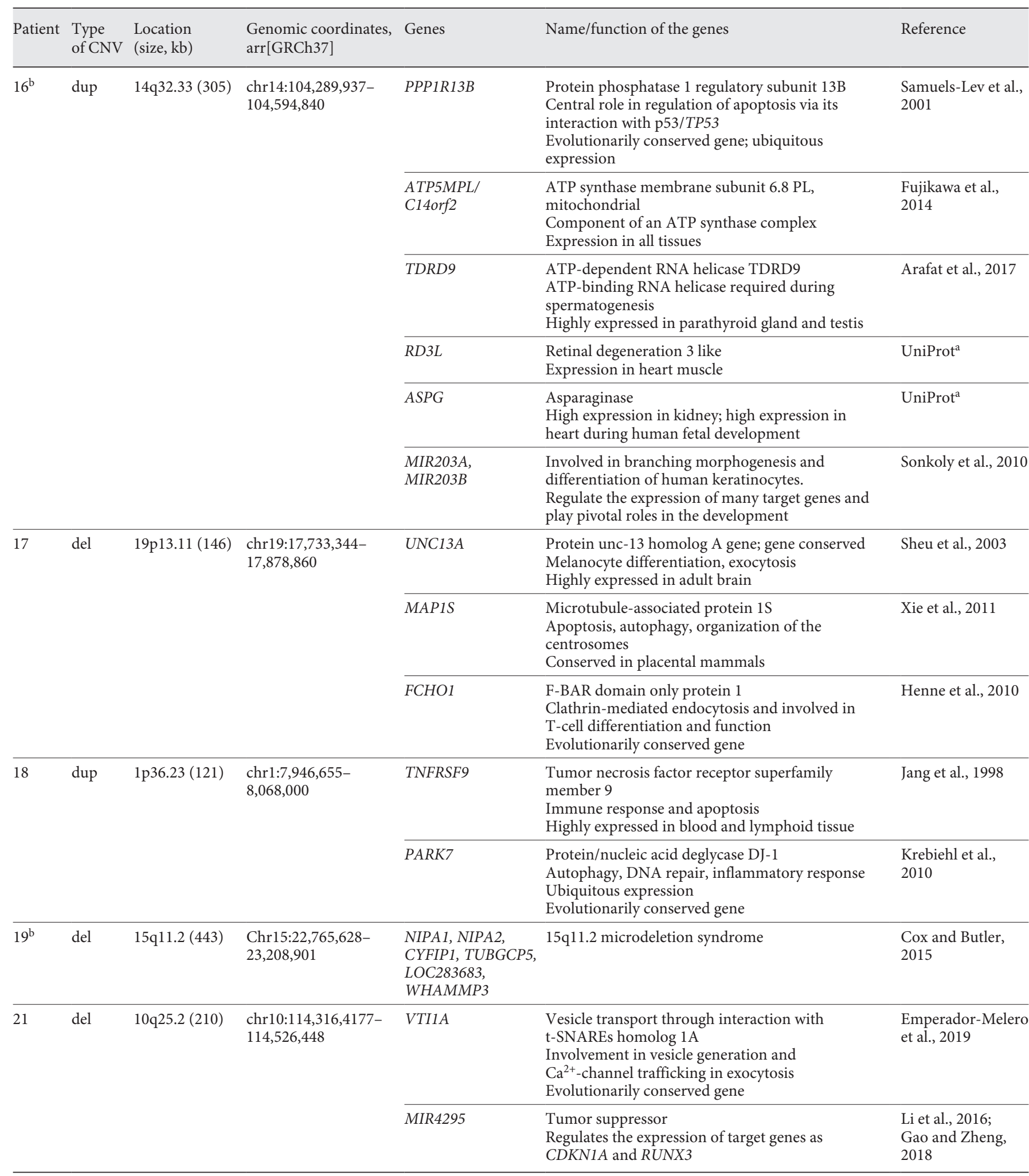

${ }^{a}$ https://www.uniprot.org/uniprot. ${ }^{b}$ Analysis of parents: healthy mother carrying the CNV. Other databases consulted: https://www.ncbi.nlm.nih.gov/ gene/, https://www.proteinatlas.org/, http://dbsearch.clinicalgenome.org/search/, http://dgv.tcag.ca/gb2/gbrowse/dgv2_hg19/. del, deletion; dup, duplication. 


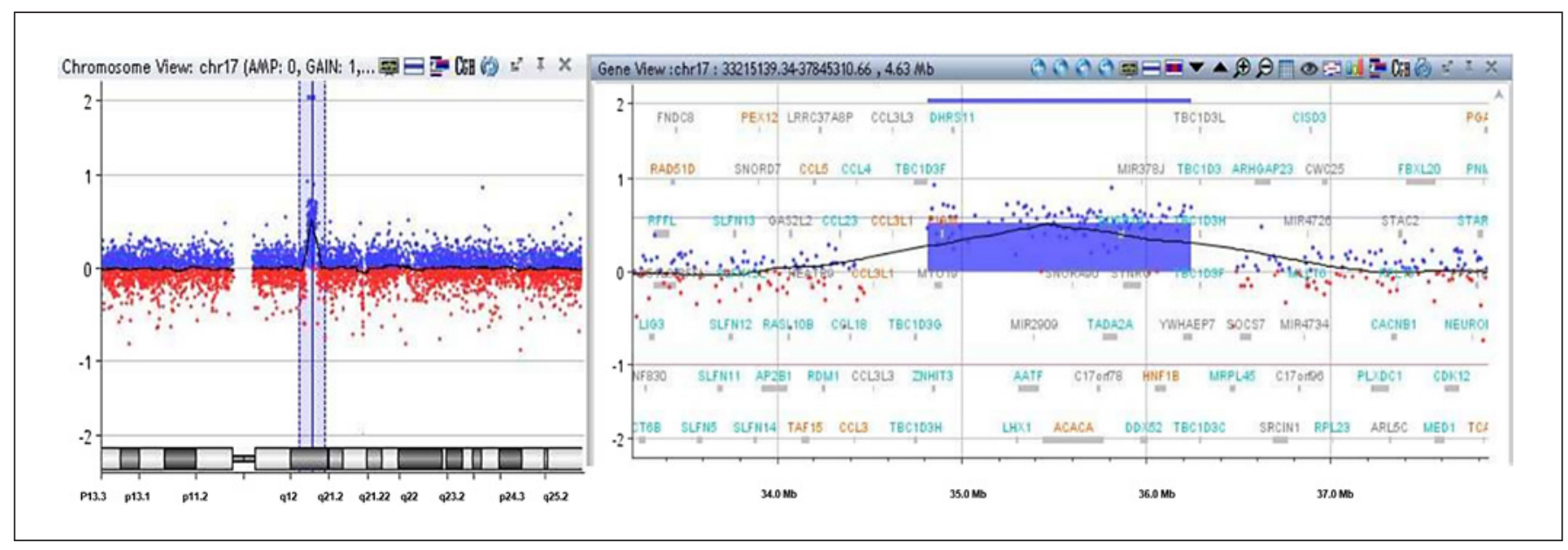

Fig. 3. Array-CGH for chromosome 17 in case 11. Data analysis by CytoGenomics software is shown. The left image shows the duplicated region in 17q12; the involved genes in this CNV are shown in the right image.

indicating that the frequency of these types of defects among VACTERL patients is greater than $50 \%$ and thus one of the most common anomalies [Reutter et al., 2016; Husain et al., 2018].

To clarify the pathophysiology, previous works have suggested that patients with VACTERL association might be subdivided into "upper" and "lower" groups: patients with cardiac malformations belong to the upper group, and patients with renal defects belong to the lower group [Källén et al., 2001]. However, as patients in our study with renal anomalies also had cardiac defects, it was difficult for us to separate them into these 2 groups. This cooccurrence of both types of birth defects (cardiac and renal anomalies) has been reported in patients, and it has been suggested that there may be a common genetic cause for the occurrence of both anomalies [Gabriel et al., 2018]. The above highlights the fact that one mechanism underlying the physiopathology may be common for all VACTERL patients, including those with different clinical features.

Genetic factors as a cause of VACTERL association have also been investigated and suggested in its etiology. This is due to some observations: (1) the existence of families with at least 2 affected members; (2) the presence of de novo variants in some patients, found in genes that act during embryonic development; and (3) the presence of chromosomal microalterations that affect gene-bearing regions involved in fetal development [Solomon et al., 2010a, b; Hilger et al., 2012; Reutter et al., 2016]. In our cohort, none of the cases had a family history of similar phenotypes or the presence of CNVs for other clinical causes. Interestingly, the aCGH results allowed us to detect CNVs in 10 patients: CNVs in 8 cases were classified as VUS and are new; in the other 2 cases, CNVs were identified as a deletion in 15q11.2 and a duplication in 17q12. Both alterations are associated with well-known genetic syndromes (OMIM 615656 and 614526) not previously diagnosed in our cohort.

Several CNVs have been reported as a frequent finding in patients with different types of congenital malformations, including those affected with VACTERL association; however, for the vast majority of these regions, their effects on phenotypes are unknown [Nguyen et al., 2017; Zhang et al., 2017]. The CNVs found in the 8 patients of our cohort have not been previously related to the condition, and the affected genes in these regions have not been associated with the etiology. The CNVs detected in our patients involve genes implicated in different cellular processes, such as apoptosis, endocytosis, energy metabolism, response to oxidative stress, intracellular trafficking, immune response, and gene regulation, among others. Although these CNVs have not yet been associated with the disease, these molecular processes are important in embryonic development [Stevenson and Hunter, 2013]. Several genes located in the regions of the CNVs have also been implicated in other diseases or have been related to cancer (Table 2). On the other hand, alterations in regions that encode some microRNAs were also found (Table 2), findings that are consistent with previous reports in which the regulatory role of the miRNAs is highly implicated in embryonic development [Allis et al., 2015; Alberti and Cochella, 2017]. 
The CNV by microdeletion at $19 \mathrm{p} 13.11$ in case 17 (male patient with anal atresia, recto-perineal fistula, thoracic hemivertebrae, thoracic butterfly-shaped vertebrae, alterations of segmentation in the cervical vertebrae, supernumerary ribs, and left renal agenesis) is a region with 3 interesting genes involved in maintaining cellular homeostasis. The MAP1S gene has been related to autophagy regulation in all tissues and has been associated with renal fibrosis, heart disease, neurodegenerative diseases, and some cancers, among others [Xie et al., 2011; Xu et al., 2016]. Autophagy is an evolutionarily conserved process in all eukaryotic organisms and plays a key role in maintaining cellular homeostasis during embryonic development and differentiation [Martinet et al., 2009; Boya et al., 2018; Levine and Kroemer, 2019]. FCHO1 is another gene involved in clathrin-mediated endocytosis and in T-cell development and function in humans [Sheu et al., 2003; Łyszkiewicz et al., 2020]. Silencing of $f$ cho1 in zebrafish embryos causes alterations in morphogenesis [Umasankar et al., 2012]. The UNC13A/MUNC13A-1 gene is evolutionarily conserved and involved in vesicle maturation during exocytosis in the synaptic process [Brose and Rosenmund, 2002; Magdziarek et al., 2020]. Homozygous mutations in this gene have been associated with microcephaly and abnormal cortical electrical activity [Engel et al., 2016]. It is striking that the cellular processes in which these genes participate are highly active during embryogenesis [Mizushima and Levine, 2010]. We may then propose that alteration in protein levels might affect, to some extent, the balance of the processes of embryonic morphogenesis, such as those presented by the patient.

The duplication at $1 \mathrm{p} 36.23$ of patient 18 involves the PARK7 gene. This is an interesting gene because it is involved in multiple cellular processes, such as in autophagy and endocytosis, as a redox-sensitive chaperone and as a sensor for oxidative stress, among others [Lee et al., 2018]. Mutations in this gene have been highly associated with autosomal recessive Parkinson disease [Kasten et al., 2018]. However, in our patient, the gene was duplicated, and the effects of this on development are unknown. The TAF12 gene is involved in the duplication at 1q31.1 in case 9 , and the encoded protein is reported to have DNAbinding transcription factor activity and is implicated in cancer [Tong et al., 2015]. Patient 13 carried a duplication at $12 \mathrm{p} 12.1$, involving the PYROXD1 gene. This gene is evolutionarily conserved in eukaryotes, and deficiency of the protein due to mutations may cause alterations in the proliferation, migration, and differentiation of myoblasts [Reutter et al., 2016; Auranen et al., 2019]. The function-

Phenotype and CNVs in Patients with VACTERL Association al effect on the phenotype when the gene is entirely duplicated is unknown.

The THOC1 gene was found in the duplicated $18 \mathrm{q} 12$ region and encodes a component of the TREX complex. This complex is evolutionarily conserved across a wide range of organisms and plays a central role in mRNA export [Wang et al., 2007]. Among other cellular functions, TREX is necessary for maintaining differentiation during embryogenesis [Heath et al., 2016]. The CLUL1 gene, located in the same region, has been found to be differentially methylated (hypomethylated) in the placentas of newborns with congenital heart defects [Radhakrishna et al., 2019]; however, no association with cardiac development has been reported before. It reportedly overregulates many different forms of neurodegeneration [Talmud et al., 2009]. Notably, epigenetic alterations have also been mentioned as a probable cause of VATER/ VACTERL possibly associated with environmental factors [Solomon, 2018; Lubinsky, 2019].

Another gene that also needs to be mentioned is the PCNX1 gene located at 14q24.2 affected by duplication in patient 12 . This gene is highly conserved among species. Although its role in mammals is not well known, it has been studied in Drosophila, demonstrating that it is related to the NOTCH signaling pathway and may play a role in vesicular transport during neuroblast segregation of the neuroectoderm [Yamakawa et al., 2018. The NOTCH signaling pathway is known to be involved in the formation of anatomical structures affected in VACTERL association, such as the development of the cardiovascular system and the spine [Stevenson and Hunter, 2013].

Other genes found in the CNVs of our patients have some important cellular functions, as described in Table 2. Regarding CNVs related to known syndromes, the deletion at 15q11.2 has been reported to be a variant causing variable expression and incomplete penetrance affecting the genes NIPA1, NIPA2, CYFIP1, and TUBGCP5 located in the nonimprinted area. These genes are highly conserved, and their alteration causes neurological, cognitive, and behavioral problems [Cox and Butler, 2015]. The phenotype of the patient displays several nonclassical clinical characteristics for this syndrome, resulting in inclusion as VACTERL. It is possible that other genetic or environmental factors contributed to the etiology of the phenotype, which must be confirmed. On the other hand, microdeletions and microduplications of the $17 \mathrm{q} 12$ region have been reported in patients with VACTERL association [Zhang et al., 2017]. Our patient had esophageal atresia with tracheoesophageal fistula plus renal and 
thumb anomalies, similar to patients reported previously. The HNF1B gene in this region has been implicated in renal anomalies and tracheoesophageal fistula in these patients [Smigiel et al., 2014; Zhang et al., 2017; Saha et al., 2018]; thus, it has been suggested that this chromosomal region poses a risk for expression of VATER/VACTERL phenotypes.

FA, which is a differential diagnosis of VACTERL-H association, is particularly noteworthy, as patients with this condition have a high risk of hematologic abnormalities including bone marrow failure, myelodysplastic syndrome or leukemia, and congenital anomalies that may be a part of the VACTERL-H association [Alter and Rosenberg, 2013; Savage et al., 2016; Fiesco-Roa et al., 2019]. The availability of chromosomal breakage tests as a sensitive indicator for FA makes it especially important not to miss this critical diagnosis among VACTERL-H suspicious patients. Previous reports highlight the necessity of performing FA testing because compared to patients without FA-VACTERL phenotypes, more than $90 \%$ of patients with FA-VACTERL phenotypes have both renal and limb anomalies, and in more than 50\%, these findings are combined with congenital heart disease [Alter and Rosenberg, 2013; Fiesco-Roa et al., 2019]. Despite the fact that in our study, 6 cases $(33.3 \%)$ had upper limb anomalies plus renal defects, and in 4 cases $(22 \%)$, these were accompanied by a cardiac defect, none of the cases showed sensitivity in in vitro DEB culture. Therefore, FA was ruled out in our cohort. This finding in our patients should not rule out the chromosomal fragility test for the differential diagnosis of patients with VACTERL.

The diversity of differential diagnoses among patients with VACTERL emphasizes the importance of clinical evaluation by a medical geneticist in all patients. Genetic testing is available for certain conditions that have features overlapping with those of VACTERL association, and these conditions need to be ruled out [Solomon, 2011]. Such genetic testing can be helpful for assigning a diagnosis and identifying associated medical problems that should be evaluated for establishing prognosis and for genetic counseling purposes. One limitation of our study is that not all patients underwent molecular testing for other genetic syndromes; nonetheless, all underwent clinical evaluation by a medical geneticist who did not find any specific features to suggest a particular syndrome. By molecular cytogenetic analysis, we were able to reclassify 2 patients, and VACTERL diagnosis was finally ruled out. VACTERL association is still considered a diagnosis of exclusion, and aCGH genetic testing is im- portant to rule out other genetic causes of VACTERL phenotypes [Winberg et al., 2014].

The CNVs classified as VUS reported herein harbor some very interesting genes involved in cellular homeostasis; for example, MAP1S, USP14, and PARK7 are associated with autophagy, FCHO1, UNC13A, and VTI1A with endocytosis/exocytosis, COLEC12 with phagocytosis, and GMEB1, PPP1R13B, THOC1, and MAP1S with apoptosis, in addition to other genes with other functions. Overall, our findings highlight a large number of genes identified in CNVs with functions in processes that are active during embryonic development.

It is important to note that more studies are needed to further evaluate the chromosomal regions involved in the CNVs found in our patients because they might be regions of interest due to their gene content and the complexity of the birth defects of some of the patients. Complementary studies such as functional studies and/or next-generation sequencing molecular tests are also necessary to determine the inheritance patterns of the VUS and to elucidate the complex genetic etiology of the VATER/VACTERL phenotypes in the remaining cases analyzed.

\section{Acknowledgments}

We gratefully thank the patients who participated in this study at the Hospital Universitario San Ignacio and the different hospitals in Bogotá city that referred the patients. Additionally, we thank the geneticists who referred some of the patients and the residents of the specialization in Clinical Genetics for attending to the patients and to Sistemas Genómicos for help with the sample analysis.

\section{Statement of Ethics}

This study was performed in accordance with the Code of Ethics of the World Medical Association (Declaration of Helsinki) and approved by the Ethics Institutional Review Board of the School of Medicine of Pontificia Universidad Javeriana, Bogotá and Hospital Universitario San Ignacio (approval No. 2014/107). Written informed consent, approved by the Ethics Committee, was obtained from all participants.

\section{Conflict of Interest Statement}

The authors have no conflicts of interest to declare. 


\section{Funding Sources}

This work was funded by Pontificia Universidad Javeriana and Hospital Universitario San Ignacio, ID 00006284, Ref: 2014-107. A.H. also received a Young Researcher grant from COLCIENCIAS (0226/2014).

\section{Author Contributions}

O.M.M., A.I.S, A.H., and A.S.C. performed cytogenetic and molecular experiments and contributed to writing the paper. G.G., F.S., J.C.P., M.O., and Y.V. performed clinical analysis, followed the patient, obtained clinical information for the paper, and contributed to writing the paper. O.M.M., A.R., J.B., and J.S. applied for and obtained funding for the project, directed the work, and wrote the paper.

\section{References}

Alberti C, Cochella L. A framework for understanding the roles of miRNAs in animal development. Development. 2017;144(14):254859.

Allis D, Caparros ML, Jenuwein T, Reinberg D. Epigenetics, 2nd ed. Cold Spring Harbor: Cold Spring Harbor Laboratory Press; 2015.

Alter BP, Rosenberg PS. VACTERL-H association and Fanconi anemia. Mol Syndromol. 2013;4(1-2):87-93.

Arafat M, Har-Vardi I, Harlev A, Levitas E, Zeadna $\mathrm{A}$, Abofoul-Azab $\mathrm{M}$, et al. Mutation in TDRD9 causes non-obstructive azoospermia in infertile men. J Med Genet. 2017;54(9): 633-9.

Auerbach AD. A test for Fanconi's anemia. Blood. 1988;72(1):366.

Auranen M, Palmio J, Friant S, Lapatto H, Paetau A, Ojanen S, et al. Recessive PYROXD1 mutations cause adult-onset limb-girdle-type muscular dystrophy. J Neurol. 2019;266(2):35360.

Bierhals T, Maddukuri SB, Kutsche K, Girisha KM. Expanding the phenotype associated with $17 \mathrm{q} 12$ duplication: case report and review of the literature. Am J Med Genet A. 2013;161A(2):352-9.

Boya P, Codogno P, Rodriguez-Muela N. Autophagy in stem cells: repair, remodelling and metabolic reprogramming. Development. 2018;145(4):dev146506.

Brose N, Rosenmund C. Move over protein kinase $C$, you've got company: alternative cellular effectors of diacylglycerol and phorbol esters. J Cell Sci. 2002;115(23):4399-411.

Chen Y, Liu Z, Chen J, Zuo Y, Liu S, Chen W, et al. The genetic landscape and clinical implications of vertebral anomalies in VACTERL association. J Med Genet. 2016;53(7):431-7.

Cox DM, Butler MG. The 15q11.2 BP1-BP2 microdeletion syndrome: a review. Int J Mol Sci. 2015;16(2):4068-82.

Dworschak GC, Draaken M, Marcelis C, de Blaauw I, Pfundt R, van Rooij IA, et al. De novo $13 \mathrm{q}$ deletions in two patients with mild anorectal malformations as part of VATER/ VACTERL and VATER/VACTERL-like association and analysis of EFNB2 in patients with anorectal malformations. Am J Med Genet A. 2013;161A(12):3035-41.

Emperador-Melero J, Toonen RF, Verhage M. Vti proteins: beyond endolysosomal trafficking. Neuroscience. 2019;420:32-40.
Engel AG, Selcen D, Shen XM, Milone M, Harper CM. Loss of MUNC13-1 function causes microcephaly, cortical hyperexcitability, and fatal myasthenia. Neurol Genet. 2016;2(5): e105.

Errabolu R, Sanders MA, Salisbury JL. Cloning of a cDNA encoding human centrin, an EFhand protein of centrosomes and mitotic spindle poles. J Cell Sci. 1994;107(Pt 1):9-16.

Fiesco-Roa MO, Giri N, McReynolds LJ, Best AF, Alter BP. Genotype-phenotype associations in Fanconi anemia: a literature review. Blood Rev. 2019;37:100589.

Fujikawa M, Ohsakaya S, Sugawara K, Yoshida M. Population of ATP synthase molecules in mitochondria is limited by available $6.8-\mathrm{kDa}$ proteolipid protein (MLQ). Genes Cells. 2014;19(2):153-60.

Gabriel GC, Pazour GJ, Lo CW. Congenital heart defects and ciliopathies associated with renal phenotypes. Front Pediatr. 2018;6:175.

Gao Q, Zheng J. Ginsenoside Rh2 inhibits prostate cancer cell growth through suppression of microRNA-4295 that activates CDKN1A. Cell Prolif. 2018;51(3):e12438.

Gazit K, Moshonov S, Elfakess R, Sharon M, Mengus $\mathrm{G}$, Davidson I, et al. TAF4/4b x TAF12 displays a unique mode of DNA binding and is required for core promoter function of a subset of genes. J Biol Chem. 2009;284(39):26286-96.

Graham SA, Antonopoulos A, Hitchen PG, Haslam SM, Dell A, Drickamer K, et al. Identification of neutrophil granule glycoproteins as Lewis(x)-containing ligands cleared by the scavenger receptor C-type lectin. J Biol Chem. 2011;286(27):24336-49.

Heath CG, Viphakone N, Wilson SA. The role of TREX in gene expression and disease. Biochem J. 2016;473(19):2911-35.

Henne WM, Boucrot E, Meinecke M, Evergren E, Vallis Y, Mittal R, et al. FCHo proteins are nucleators of clathrin-mediated endocytosis. Science. 2010;328(5983):1281-4.

Hilger A, Schramm C, Draaken M, Mughal SS, Dworschak G, Bartels E, et al. Familial occurrence of the VATER/VACTERL association. Pediatr Surg Int. 2012;28(7):725-9.

Hilger A, Schramm C, Pennimpede T, Wittler L, Dworschak GC, Bartels E, et al. De novo microduplications at $1 \mathrm{q} 41,2 \mathrm{q} 37.3$, and $8 \mathrm{q} 24.3$ in patients with VATER/VACTERL association. Eur J Hum Genet. 2013;21(12):1377-82.
Hilger AC, Halbritter J, Pennimpede T, van der Ven A, Sarma G, Braun DA, et al. Targeted resequencing of 29 candidate genes and mouse expression studies implicate ZIC3 and FOXF1 in human VATER/VACTERL association. Hum Mutat. 2015;36(12):1150-4.

Holden ST, Cox JJ, Kesterton I, Thomas NS, Carr C, Woods CG. Fanconi anaemia complementation group B presenting as X linked VACTERL with hydrocephalus syndrome. J Med Genet. 2006;43(9):750-4.

Husain M, Dutra-Clarke M, Lemieux B, Wencel M, Solomon BD, Kimonis V. Phenotypic diversity of patients diagnosed with VACTERL association. Am J Med Genet A. 2018;176(9): 1830-7.

Jang IK, Lee ZH, Kim YJ, Kim SH, Kwon BS. Human 4--1BB (CD137) signals are mediated by TRAF2 and activate nuclear factor-kappa $B$. Biochem Biophys Res Commun. 1998;242(3): 613-20.

Jung M, Ramanagoudr-Bhojappa R, van Twest S, Rosti RO, Murphy V, Tan W, et al. Association of clinical severity with FANCB variant type in Fanconi anemia. Blood. 2020;135(18): 1588-602.

Källén K, Mastroiacovo P, Castilla EE, Robert E, Källén B. VATER non-random association of congenital malformations: study based on data from four malformation registers. Am J Med Genet. 2001;101(1):26-32.

Kasten M, Hartmann C, Hampf J, Schaake S, Westenberger A, Vollstedt EJ, et al. Genotype-phenotype relations for the Parkinson's disease genes Parkin, PINK1, DJ1: MDSGene Systematic Review. Mov Disord. 2018;33(5):730-41.

Kim J, Kim P, Hui CC. The VACTERL association: lessons from the Sonic hedgehog pathway. Clin Genet. 2001;59(5):306-15.

Kim E, Park S, Lee JH, Mun JY, Choi WH, Yun Y, et al. Dual function of USP14 deubiquitinase in cellular proteasomal activity and autophagic flux. Cell Rep. 2018;24(3):732-43.

Krebiehl G, Ruckerbauer S, Burbulla LF, Kieper $\mathrm{N}$, Maurer B, Waak J, et al. Reduced basal autophagy and impaired mitochondrial dynamics due to loss of Parkinson's disease-associated protein DJ-1. PLoS ONE. 2010;5(2):e9367.

Lee DH, Kim D, Kim ST, Jeong S, Kim JL, Shim $\mathrm{SM}$, et al. PARK7 modulates autophagic proteolysis through binding to the N-terminally arginylated form of the molecular chaperone HSPA5. Autophagy. 2018;14(11):1870-85. 
Levine B, Kroemer G. Biological Functions of Autophagy Genes: A Disease Perspective. Cell. 2019;176(1-2):11-42.

Li X, Zheng J, Diao H, Liu Y. RUNX3 is downregulated in glioma by Myc-regulated miR4295. J Cell Mol Med. 2016;20(3):518-25.

Lubinsky M. Sonic Hedgehog. VACTERL, and Fanconi anemia: pathogenetic connections and therapeutic implications. Am J Med Genet Part. 2015;A167A:2594-8.

Lubinsky M. The VACTERL association: mosaic mitotic aneuploidy as a cause and a model. J Assist Reprod Genet. 2019;36(8):1549-54.

Łyszkiewicz M, Ziętara N, Frey L, Pannicke U, Stern M, Liu Y, et al. Human FCHO1 deficiency reveals role for clathrin-mediated endocytosis in development and function of $\mathrm{T}$ cells. Nat Commun. 2020;11(1):1031.

Magdziarek M, Bolembach AA, Stepien KP, Quade B, Liu X, Rizo J. Re-examining how Munc13-1 facilitates opening of syntaxin-1. Protein Sci. 2020;29(6):1440-58.

Martinet W, Agostinis P, Vanhoecke B, Dewaele M, De Meyer GR. Autophagy in disease: a double-edged sword with therapeutic potential. Clin Sci. 2009;116(9):697-712.

Miller SA, Dykes DD, Polesky HF. A simple salting out procedure for extracting DNA from human nucleated cells. Nucleic Acids Res. 1988;16(3):1215.

Mitchell E, Douglas A, Kjaegaard S, Callewaert B, Vanlander A, Janssens S, et al. Recurrent duplications of $17 \mathrm{q} 12$ associated with variable phenotypes. Am J Med Genet A. 2015; 167A(12):3038-45.

Mizushima N, Levine B. Autophagy in mammalian development and differentiation. Nat Cell Biol. 2010;12(9):823-30.

Nakagawa T, Tsuruma K, Uehara T, Nomura Y. GMEB1, a novel endogenous caspase inhibitor, prevents hypoxia- and oxidative stressinduced neuronal apoptosis. Neurosci Lett. 2008;438(1):34-37.

Nguyen LT, Fleishman R, Flynn E, Prasad R, Moulick A, Mesia CI, et al. 22q11.2 microduplication syndrome with associated esophageal atresia/tracheo-esophageal fistula and vascular ring. Clin Case Rep. 2017;5(3):351-6.

Porteous ME, Cross I, Burn J. VACTERL with hydrocephalus: one end of the Fanconi anemia spectrum of anomalies?. Am J Med Genet. 1992;43(6):1032-4.

Puvabanditsin S, Van Gurp J, February M, Khali M, Mayne J, Ai McConnell J, et al. VATER/ VACTERL association and caudal regression with Xq25-q27.3 microdeletion: a case report. Fetal Pediatr Pathol. 2016;35(2):133-41.

Quan L, Smith DW. The VATER association: vertebral defects, anal atresia, tracheoesophageal fistula with esophageal atresia, radial dysplasia. In: Bergsma D, editor. The Clinical Delineation of Birth Defects. Volume XII. G.I. Tract including Liver and Pancreas. Baltimore: The Williams and Wilkins company; 1972. p. $75-8$
Quan L, Smith DW. The VATER association Vertebral defects, anal atresia,T-E fistula with esophageal atresia, radial and renal dysplasia: a spectrum of associated defects. J Pediatr. 1973;82:104-7.

Radhakrishna U, Albayrak S, Zafra R, Baraa A, Vishweswaraiah S, Veerappa AM, et al. Placental epigenetics for evaluation of fetal congenital heart defects: ventricular septal defect (VSD). PLoS ONE. 2019;14(3):e0200229.

Reutter H, Hilger AC, Hildebrandt F, Ludwig M. Underlying genetic factors of the VATER/ VACTERL association with special emphasis on the "Renal" phenotype. Pediatr Nephrol. 2016;31(11):2025-33.

Rittler M, Paz JE, Castilla EE. VACTERL association, epidemiologic definition and delineation. Am J Med Genet. 1996;63(4):529-36.

Saha M, Reddy HM, Salih MA, Estrella E, Jones MD, Mitsuhashi S, et al. Impact of PYROXD1 deficiency on cellular respiration and correlations with genetic analyses of limb-girdle muscular dystrophy in Saudi Arabia and Sudan. Physiol Genomics. 2018;50(11):929-39.

Saisawat P, Kohl S, Hilger AC, Hwang DY, Yung Gee H, Dworschak GC, et al. Whole-exome resequencing reveals recessive mutations in TRAP1 in individuals with CAKUT and VACTERL association. Kidney Int. 2014; 85(6):1310-7.

Samuels-Lev Y, O'Connor DJ, Bergamaschi D, Trigiante G, Hsieh JK, Zhong S, et al. ASPP proteins specifically stimulate the apoptotic function of p53. Mol Cell. 2001;8(4):781-94.

Savage SA, Ballew BJ, Giri N, NCI DCEG Cancer Genomics Research Laboratory, Chandrasekharappa SC, Chandrasekharappa SC, Ameziane N, et al. Novel FANCI mutations in Fanconi anemia with VACTERL association. Am J Med Genet A. 2016;170A(2):386-91.

Schramm C, Draaken M, Bartels E, Boemers TM, Aretz S, Brockschmidt FF, et al. De novo microduplication at 22q11.21 in a patient with VACTERL association. Eur J Med Genet. 2011;54(1):9-13.

Shaw-Smith C. Genetic factors in esophageal atresia, tracheo-esophageal fistula and the VACTERL association: Roles for FOXF1 and the 16q24.1 FOX transcription factor gene cluster, and review of the literature. Eur J Med Genet. 2010;53(1):6-13.

Sheu L, Pasyk EA, Ji J, Huang X, Gao X, Varoqueaux $\mathrm{F}$, et al. Regulation of insulin exocytosis by Munc13-1. J Biol Chem. 2003; 278(30):27556-63.

Siebel S, Solomon BD. Mitochondrial factors and VACTERL association-related congenital malformations. Mol Syndromol. 2013;4(1-2): 63-73.

Smigiel R, Marcelis C, Patkowski D, de Leeuw N, Bednarczyk D, Barg E, et al. Oesophageal atresia with tracheoesophageal fistula and anal atresia in a patient with a de novo microduplication in 17q12. Eur J Med Genet. 2014; 57(1):40-3.
Solomon BD. The etiology of VACTERL association: current knowledge and hypotheses. Am J Med Genet C Semin Med Genet. 2018; 178(4):440-6.

Solomon BD. VACTERL/VATER Association. Orphanet J Rare Dis. 2011;6:56.

Solomon BD, Pineda-Alvarez DE, Raam MS, Bous SM, Keaton AA, Vélez JI, et al. Analysis of component findings in 79 patients diagnosed with VACTERL association. Am J Med Genet A. 2010b;152A(9):2236-44.

Solomon BD, Pineda-Alvarez DE, Raam MS Cummings DA. Evidence for inheritance in patients with VACTERL association. Hum Genet. 2010a;127(6):731-3.

Solomon B, Baker LA, Bear KA, Cunningham BK, Giampietro PF, Hadigan C, et al. An approach to the identification of anomalies and etiologies in neonates with identified or suspected VACTERL (vertebral defects, anal atresia, tracheo-esophageal fistula with esophageal atresia, cardiac defects, renal and limb anomalies) association. J Pediatr. 2014;164(3):451-7.

Sonkoly E, Wei T, Pavez Loriè E, Suzuki H, Kato $\mathrm{M}$, Törmä $\mathrm{H}$, et al. Protein kinase C-dependent upregulation of miR-203 induces the differentiation of human keratinocytes. J Invest Dermatol. 2010;130(1):124-34.

Stankiewicz P, Sen P, Bhatt SS, Storer M, Xia Z, Bejjani BA, et al. Genomic and genic deletions of the FOX gene cluster on 16q24.1 and inactivating mutations of FOXF1 cause alveolar capillary dysplasia and other malformations. Am J Hum Genet. 2009;84(6):780-91.

Stevenson RE, Hunter AG. Considering the embryopathogenesis of VACTERL association. Mol Syndromol. 2013;4(1-2):7-15.

Talmud PJ Drenos F, Shah S, Shah T, Palmen J, Verzilli C, et al. Gene-centric association signals for lipids and apolipoproteins identified via the HumanCVD BeadChip. Am J Hum Genet. 2009;85(5):628-42.

Temtamy SA, Miller JD. Extending the scope of the VATER association: definition of the VATER syndrome. J Pediatr. 1974;85(3):345-9.

Thauvin-Robinet C, Faivre L, Huet F, Journeau P, Glorion C, Rustin P, et al. Another observation with VATER association and a complex IV respiratory chain deficiency. Eur J Med Genet. 2006;49(1):71-7.

Tong Y, Merino D, Nimmervoll B, Gupta K, Wang YD, Finkelstein D, et al. Cross-species genomics identifies TAF12, NFYC, and RAD54L as choroid plexus carcinoma oncogenes. Cancer Cell. 2015;27(5):712-27.

Tumini S, Alfonsi M, Carinci S, Morizio E, Antonucci I, Gatta V, et al. Yq microdeletion in a patient with VACTERL association and shawl scrotum with bifid scrotum: a real pathogenetic association or a coincidence? Cytogenet Genome Res. 2019;158(3):121-125. 
Umasankar PK, Sanker S, Thieman JR, Chakraborty S, Wendland B, Tsang M, et al. Distinct and separable activities of the endocytic clathrin-coat components Fchol/2 and AP-2 in developmental patterning. Nat Cell Biol. 2012;14(5):488-501.

Wang X, Li Y, Zhang X, Goodrich DW. An allelic series for studying the mouse Thocl gene. Genesis. 2007;45(1):32-7.

Winberg J, Gustavsson P, Papadogiannakis N, Sahlin E, Bradley F, Nordenskjöld E, et al. Mutation screening and array comparative genomic hybridization using a $180 \mathrm{~K}$ oligonucleotide array in VACTERL association. PLoS One. 2014;9(1):e85313.
Winkler TW, Brandl C, Grassmann F, Gorski M, Stark K, Loss J, et al. Investigating the modulation of genetic effects on late AMD by age and sex: Lessons learned and two additional loci. PLoS One. 2018;13(3):e0194321.

Xie R, Nguyen S, McKeehan K, Wang F, McKeehan WL, Liu L. Microtubule-associated protein 1S (MAP1S) bridges autophagic components with microtubules and mitochondria to affect autophagosomal biogenesis and degradation. J Biol Chem. 2011;286(12):10367-77.
Xu G, Yue F, Huang H, He Y, Li X, Zhao H, et al. Defects in MAP1S-mediated autophagy turnover of fibronectin cause renal fibrosis. Aging (Albany NY). 2016;8(5):977-85.

Yamakawa T, Atsumi Y, Kubo S, Yamagishi A, Morita I, Matsuno K. Insight into Notch signaling steps that involve pecanex from dominant-modifier screens in Drosophila. Genetics. 2018;209(4):1099-119.

Zhang R, Marsch F, Kause F, Degenhardt F, Schmiedeke E, Märzheuser S, et al. Arraybased molecular karyotyping in 115 VATER/ VACTERL and VATER/VACTERL-like patients identifies disease-causing copy number variations. Birth Defects Res. 2017;109(13): $1063-9$. 